\title{
Fraseologismen en spreekwoorden met gendersemantiek in hedendaags Nederlands en hun Tsjechische equivalenten
}

\begin{abstract}
The aim of this article is to analyze the Dutch and Czech language in terms of idioms and the role of gender in the selected fixed expressions. The research is focused on the semantic analysis of idioms which mention gender in form and/or content. The main goal is to define and clarify how the concept of gender is represented in Dutch and Czech phraseology, to find equivalence in both languages and to confirm or reject the stereotypical understanding of gender in each society.
\end{abstract}

„Toen Adam alleen was, schiep God géén tien vrienden maar wel één Eva..."

\section{Inleiding}

De laatste jaren speelt gender in de fraseologie - vooral in Tsjechië - in toenemende mate een belangrijke rol (Issina 2013). Tot nu toe zijn er in het Nederlands en Tsjechisch slechts weinig woordenboeken te vinden die gendersemantiek betreffen. Er is dus nog een noodzaak om fraseologische eenheden met gendersemantiek te verzamelen en te beschrijven. Op het gebied van de Nederlands-Tsjechische contrastieve linguïstiek zijn er enkele belangrijke publicaties verschenen ${ }^{1}$. Hoewel de Nederlandse en Tsjechische fraseologie contrastief onderzocht zijn, werd er naar het onderwerp gender nog geen Nederlands-Tsjechische contrastieve studie gedaan die de rol van gender in fraseologismen betreft. Deze bijdrage wil op dit gebied een eerste aanzet zijn.

${ }^{1}$ Met name de studies van Handlová, K. (2012), Hrnčířová, Z. (2004) en (2001) dienen hier vermeld te worden. Zie Bibliografie. 


\section{Doelstelling en werkwijze}

Deze bijdrage stelt zich als doel om de Nederlandse en Tsjechische fraseologische eenheden met het concept 'vrouw' en het concept 'man' te selecteren, hun symboliek en betekenis in het Tsjechisch te bespreken en deze vervolgens met de Nederlandse equivalenten te vergelijken. De fraseologische eenheden met het concept 'vrouw' en het concept 'man' vormen de brondata en de fraseologische eenheden met gendersemantiek vormen de selectieve data. De resultaten van de contrastieve analyse worden weergegeven in de tabel Lijst van fraseologische eenheden met totale en gedeeltelijke equivalentie. Deze contrastieve analyse wil de Tsjechische tegenhangers van de Nederlandse fraseologische eenheden vaststellen en nagaan welke parallellen er tussen hen bestaan. Hierbij wordt niet alleen gelet op mogelijke overeenkomsten op het gebied van betekenis en beeldspraak, maar ook op mogelijke overeenkomsten met betrekking tot stilistische middelen, lexicale middelen en grammaticale structuren. De fraseologische eenheden met gendersemantiek worden op basis van de meest voorkomende associaties en symptomen ${ }^{2}$ in groepen ingedeeld op basis van stereotiepe kenmerken van mannen en vrouwen. De gegevens worden in samenvattende tabellen vermeld. Deze gegevens helpen ons om te concluderen of fraseologie de stereotiepe beelden van vrouwen en mannen (Valdrová 2006) in de maatschappij ondersteunt. Deze gegevens helpen ons verder om het belang van iedere karaktertrek in de perceptie van de genderverhoudingen door de moedertaalsprekers (gebaseerd op het aantal elementen in elke groep) vast te stellen en om te kijken in hoeverre het bepaalde symptoom belangrijk is voor het "fraseologische portret" van mannen en vrouwen (op basis van het aandeel van de f-FE en m-FE in elke groep).

Het aantal geselecteerde fraseologische eenheden, die betrekking hebben op het concept gender, helpt ons om de collectieve ideeën van moedertaalsprekers over de rollen van mannen en vrouwen in de maatschappij samen te vatten. Verder worden ook de sociale veranderingen in de maatschappij geanalyseerd. Dat betekent dat er gekeken wordt naar veranderingen in de sociale status van mannen en vrouwen in de samenleving. Op basis van de tradities wordt verwacht dat de concepten 'man' en 'vrouw' in elke geselecteerde groep naar voren komen met verschillende frequentie, gebaseerd op de gender-stereotype.

In het kader van fraseologie overheerst onenigheid in de terminologie. Als benaming voor fraseologische verschijnselen bieden zich meerdere mogenlijkheden aan. Voor een betere overzichtelijkheid worden hier de termen fraseologische eenheid (verder FE) en fraseologisme gebruikt. Deze termen worden als synoniemen gebruikt. Volgens het Van Dale Idioomwoordenboek zijn de fraseologi-

${ }^{2}$ Het aantal fraseologismen met een bepaald symptoon in elke groep bepaalt de plaats van de groep in de totale rangschikking. De volgorde van de groepen begint met de groep met het hoogste aantal fraseologismen en eindigt met de groep met het laagste aantal fraseologismen. Op soortgelijke manier wordt ook de indeling van groepen in subgroepen doorgevoerd. 
sche eenheden een aantal woorden die een karakteristieke, vaste eenheid vormen waarbij de woorden samen meer of iets anders betekenen dan de losse woorden" (Groot 1999).

In het kader van fraseologie overheerst ook onenigheid in de definitie van FE. Een goede stap in deze richting maakt Everaert (1993) die over gefixeerde expressies praat. Een gefixeerde expressie is volgens hem een combinatie van woorden waarin de verbondheid van woorden gefixeerd is. De combinatie als geheel heeft een betekenis die niet, of slechts gedeeltelijk een compositioneel is. Het syntactisch/ morfologisch gedrag van de vaste verbinding en/of delen van de vaste verbinding is niet te voorspellen vanuit het syntactisch/morfologisch gedrag van de samenstellende woorden of van de combinatie als geheel. Deze definitie is een basisdefinitie omdat het begrip 'gefixeerd' verder kan worden verklaard. Verder is het begrip frequent ten opzichte van de definitie van FE rekbaar. Het begrip is erg ruim, maar Gries (1995) stelt dat alle groepen woorden die frequenter samen voorkomen dan men statistisch zou verwachten, gefixeerde expressies kunnen worden genoemd. Hoe vaker woorden in dezelfde samenstelling en volgorde gebruikt worden, hoe meer gefixeerd ze zijn. Het is duidelijk dat fixatie een continuüm is.

Verder zijn de fraseologische eenheden polylexikaal. Dat betekent dat ze ten minste uit twee componenten bestaan. Ze zijn vast, constant in hun samenstelling en ze hebben een stabiele plaats in het lexicon. De fraseologische eenheden worden ook als één geheel beschouwd en ze zijn idiomatisch. De betekenis van de fraseologische eenheden is figuurlijk, abstract en expressief. Ze wekken ook bijbetekenissen en connotaties op.

De semantiek van fraseologismen wordt in alle taal- en culturele onderzoeken gebruikt als een heel specifieke manier van verbalisatie van ervaringen van mensen die een bepaalde samenleving creëren (Čechová 1986). Het verkrijgen en verzamelen van de gegevens over de motivatie van frasemen is essentieel voor het zoeken naar culturele informatie in taal. Dit gebeurt niet alleen door middel van algemene analyse van de fraseologische eenheden, maar ook door middel van de analyse van de componenten, omdat de taalcomponenten een belangrijke rol in genderfraseologie spelen. In dit onderzoek willen we de aandacht richten op fraseologismen met componenten die directe benamingen van vrouwen en mannen bevatten. Deze componenten noemen we de gendercomponenten, verder GK. Er bestaan ook componenten die niet direct het geslacht noemen, maar er wel naar verwijzen. Soms gaat het om symbolen van mannelijkheid of vrouwelijkheid, soms om een verwijzing naar typische eigenschappen van mannen of vrouwen door middel van bepaalde symbolen; om voorwerpen die als mannelijke of vrouwelijke attributen kunnen worden gezien en naar een man of een vrouw kunnen verwijzen. De fraseologismen die wel het concept 'vrouw' of het concept 'man' bevatten, maar over de mens in het algemeen praten, worden in dit onderzoek ook vermeld ${ }^{3}$.

3 Deze fraseologische eenheden worden vermeld omdat ze de brondata voor dit onderzoek vormen (zie p. 2) en verder om het idee te krijgen dat deze fraseologismen bestaan en om het ver- 
De lijst met fraseologische eenheden met gender-semantiek toont de overeenkomsten en verschillen van fraseologische eenheden in twee talen. Tegelijkertijd worden er de mogelijke vertalingen van idiomen vastgesteld en ook de overeenkomsten en verschillen in de metaforen en vergelijkingen die gebruikt worden in verschillende talen voor het uiten van dezelfde betekenis. De monitoring van culturele informatie in taal is ook van belang.

Een specifieke vraagstelling is naar voren gekomen tijdens het tellen van f-FE en $\mathrm{m}-\mathrm{FE}$ in elke groep. Het is niet duidelijk hoe fraseologismen, die naar beide geslachten kunnen verwijzen, moeten worden geïdentificeerd. Het gaat om fraseologismen die de betekenis van genderverhoudingen weerspiegelen waarbij het onbelangrijk is wie - vrouw of man - de actie onderneemt en om fraseologismen, die zowel in de rol van een f-FE als in de rol van een m-FE kunnen optreden. Om het eenvoudig te houden, hebben we besloten om deze fraseologismen $\mathrm{f}, \mathrm{m}$ fraseologismen te noemen (bijvoorbeeld de Tsjechische FE manželské okovy-huwelijksketens ${ }^{4}$ ).

Het corpus voor dit contrastieve onderzoek is samengesteld op basis van het Van Dale idioomwoordenboek: Verklaring en herkomst van uitdrukkingen en gezegden (1999), door H. de Groot en Slovnik české frazeologie a idiomatiky (Přirovnání, Výrazy neslovesné, Výrazy slovesné) (2009), door F. Čermák. Voorts zijn er ook andere Tsjechische en Nederlandse lexica en woordenboeken geraadpleegd, namelijk: Nederlandse spreekwoorden, spreekwijzen, uitdrukkingen en gezegden van F.A. Stoett (1981), Gevleugelde woorden: spreekwoorden, zegswijzen en andere vormen van wijsheidsliteratuur (2013), van G. Verbeek, verder Huizinga's spreekwoorden gezegden Herkomst, verklaring en vergelijking met Frans, Duits en Engels (1994) van A. Huizinga, Česká př́sloví (2013) door V. Flajšhans.

We hebben vervolgens onderzocht hoeveel fraseologismen met gendersemantiek in de zojuist genoemde bronnen opgenomen zijn. Er zijn 4 aparte groepen gevormd waarin de fraseologismen worden ingedeeld. De groepen zijn:

1. fysieke en fysiologische eigenschappen;

2. karakter van man en vrouw;

3. fraseologismen die mannen/vrouwen karakteriseren op basis van eigenschappen van de tegenovergestelde sekse;

4. fraseologismen die gendercomponenten bevatten maar geen gender semantiek hebben.

Er is een lijst van met gender verbonden fraseologische eenheden ontstaan, die het corpus van ons onderzoek vormt. Voor dit redelijk representatieve corpus

schil tussen de gender betrokken fraseologismen en de fraseologismen die geen gendersemantiek hebben te laten zien.

${ }^{4}$ Om de Tsjechische data voor de niet-Tsjechische neerlandici toegankelijk te maken, wordt er een woord-voor-woord vertaling toegevoegd. De woord-voor-woord vertaling volgt het gegeven voorbeeld van een FE in het Tsjechisch en wordt door een verbindingsstreep gemarkeerd. 
van fraseologismen is vervolgens gezocht naar Tsjechische en Nederlandse equivalenten. De resultaten zijn in een tabel opgenomen.

De opzet is om voor elk Nederlandse fraseologisme de meest adequate Tsjechische tegenhanger te vinden. Allereerst zijn alle equivalenten op hun semantiek en metaforiek en hun variaties qua vorm onderzocht. De lexicale, stilistische en grammaticale overeenkomsten zijn minder belangrijk. Vervolgens is het Tsjechische equivalent gekozen dat het meest op de Nederlandse FE lijkt qua bovengenoemde criteria.

De resultaten van ons corpus zijn in de vorm van tabellen bijeengebracht en weer ingedeeld in subtabellen die het aantal fraseologismen met een bepaalde karakteristiek samenvatten. ${ }^{5}$ Hieraan is een tabel met equivalente fraseologismen toegevoegd. We krijgen een overzicht van de hedendaagse Tsjechische en Nederlandse fraseologismen die gender-verwant zijn en op basis daarvan gaan we de stereotypen over mannen en vrouwen bevestigen.

\section{Fraseologismen: groep 1 - Karakter van man en vrouw (de innerlijke eigenschappen)}

Als eerste willen we de groep Karakter van man en vrouw onderzoeken en beschrijven. In totaal zijn er 630 fraseologismen gevonden die tot deze groep behoren. De groep wordt verder ingedeeld in twee subgroepen met het hoogste aantal fraseologismen: de groep van positieve evaluatie en negatieve evaluatie van menselijk karakter (bijvoorbeelde de Tsjechische FE holka do nepohody - een meisje voor het hondwee, kluk miliónská - een miljoenenjongen, plesnivý děděk - een beschimmelde oude man, bába jedna zatracená - een vervloekte oude vrouw en de Nederlandse FE een brave Hendrik, een zwakke broeder, een vrolijke Frans, een bedrijvige Martha, een kuise Susanna enz.). Binnen deze groepen is er een assymetrie vastgesteld omdat er meer fraseologismen - zie tabel 1 - werden gevonden die het karakter van een man betreffen (zowel negatief als positief). De fraseologismen die het karakter van een vrouw betreffen, treden minder vaak op. De termen inherent negatief en inherent positief dienen hier vermeld te worden. Niet alle FE die de eigenschappen van mannen en vrouwen beschrijven, hebben een inherent positief of een inherent negatief karakter. Dat komt door de expressiviteit van de FE. Hoewel sommige eigenschappen primair inherent positief of inherent negatief zijn, krijgen ze door de expressiviteit van één of meer woorden, die van de FE deel uitmaken, de tegenovergestelde betekenis. Deze FE behoren natuurlijk ook tot ons corpus.

5 Het is belangrijk om te melden dat een fraseologisme tot meer dan één groep kan worden gerekend omdat het met meerdere karakteristieke trekken kan worden verbonden. 
De groep Het passieve en actieve karakter van mannen en vrouwen telt het tweede hoogste aantal fraseologische eenheden. Veel fraseologismen met betrekking tot de actieve rol beschrijven een vrouw. Een vrouw wordt gezien als iemand die actie onderneemt. Een vrouw met een actief karakter wordt als positief beschouwd. Dat betreft vooral fraseologismen waar een vrouw als een energieke persoon wordt geschetst (bijvoorbeeld de Tsjechische FE holka jako jiskra - een meisje als een vonk). Een paar fraseologismen beschrijven de energieke vrouw negatief, bijvoorbeeld de Tsjechische FE být ženská jako grenadýr - een vrouw als een grenadier. Een veel voorkomend symptoom met betrekking tot de negatieve houding jegens een actieve vrouw is verbonden met de expressiviteit. De expressiviteit komt voort uit het gebruik van een "mannelijke" afbeelding van een vrouw (bijvoorbeeld de Tsjechische FE ženská jako granátník - een vrouw als grenadier). In dit geval wordt er voor een vrouw meestal het beeld van een man gebruikt. Een interessante situatie doet zich voor wanneer de krachtdadigheid, het ondernemerschap en het actieve gedrag van vrouwen zelf positief worden ervaren. Als deze eigenschappen echter met het mannelijk karakter worden geassocieerd, wordt de energieke vrouw negatief gezien (bijvoorbeeld de Tsjechische FE ženská jako generál - een vrouw als een generaal). In de bovengenoemde groepen worden vrouwen van verschillende leeftijden beschreven. De activiteit van een jonge vrouw verschijnt met betrekking tot levendigheid en alertheid, en vaak wordt deze eigenschap gecombineerd met andere eigenschappen, zoals aspiraties en scherpzinnigheid (bijvoorbeeld de Tsjechische FE holka jako brousek - een meisje als een slijpsteen). Het beeld van zo'n vrouw wordt positief beoordeeld. De m-FE die tot de semantische groep 'actief' behoren, zijn identiek met de f-FE, zowel formeel als semantisch.

Een interessante semantische groep wordt gevormd door fraseologismen die een passief karakter beschrijven. Passiviteit wordt alleen als een negatieve eigenschap gezien. Veel uitdrukkingen uit deze groep beschrijven een vrouw als bescheiden en met een rustige natuur (bijv. de Tsjechische FE být zticha jako put'ka - zwijgen als een huisluilak) maar de betekenis is ironisch en minachtend.

Spraakzaamheid, boosheid en kibbeligheid komen heel vaak als negatieve karaktereigenschappen van vrouwen voor. In beide talen zijn er veel fraseologismen gevonden met betrekking tot deze eigenschappen. In het geval van deze groep kunnen we praten over een rijke assymetrie. De meerderheid van de FE wordt gevormd door FE die een vrouw karakteriseren. Het beeld van zo' $n$ vrouw wordt niet alleen geïdentificeerd met directe benamingen, maar ook met een bepaald symbool, dat meestal specifiek voor een vrouw is, bijv. kolovrátek (draaiorgel) of metla (bezem). De FE, die in het Tsjechisch bestaat, huba jí jede jako kolovrátek haar mond draait als een draaiorgel, is hier een bewijs van. Wat betreft de semantische bijzonderheden in verband met uitdrukkingen die tot deze groep behoren, moet worden opgemerkt dat in veel gevallen spraakzaamheid wordt verbonden met een andere negatieve karakteristiek, namelijk kibbeligheid (bijvoorbeel de 
Tsjechische FE mit hubu jak šlejfiřka - een mond hebben als een slijper - en de Nederlandse FE schelden als een viswijf). Zowel m-FE als f-FE hebben in deze groep een negatieve connotatie. Dit heeft te maken met het feit dat kibbeligheid in elke taal/maatschappij als een negatieve menselijke eigenschap wordt gezien.

De FE die de karaktereigenschappen van masculiniteit en femininiteit beschrijven vormen een kleine groep van fraseologismen. Er zijn meer f-FE gevonden binnen deze groep. De fraseologismen zijn heel stereotiep wat de kijk op het karakter van mannen en vrouwen betreft. Binnen het semantische perspectief bestaat er overeenstemming tussen de f-FE en m-FE en tussen beide talen. In de naïeve beschrijving van de wereld worden feminiene en masculiene eigenschappen als positief gezien wat de stereotiepe eigenschappen van mannen en vrouwen betreft. Een als positief beschouwde vrouw is een leuke en gehoorzame vrouw die haar huishouden boven alles stelt (bijvoorbeeld de Nederlandse FE een goede kip legt haar ei thuis), en een positief geclassificeerde man is een stoere man die zijn gezin financieel kan onderhouden (bijvoorbeeld de Tsjechische FE pravý chlapde ware man). Vrouwen en mannen die niet genoeg femininiteit of masculiniteit in zich hebben, worden negatief beordeeld.

Trots en hooghartigheid zijn andere karaktereigenschappen die in ons corpus van fraseologismen zijn vastgesteld. Er zijn echter niet veel uitdrukkingen met deze connotatie vastgesteld (als voorbeeld kiezen we voor de Nederlandse FE zo trots als een pauw, dat ook in het Tsjechisch bestaat - pyšnýjako páv - trots als een pauw). Deze eigenschappen worden in het linguïstische beeld van de wereld als negatief geëvalueerd, en beide geslachten worden vanwege deze karaktertrek veroordeeld. Het grootste aantal fraseologismen heeft hier een negatieve connotatie. Als we het over de beeldspraak van fraseologismen hebben, wordt het hooghartige gedrag van mannen en vrouwen in het Tsjechisch het vaakst vergeleken met het gedrag van de adel.

Ijver, luiheid en onvermogen vormen een andere subgroep. Deze groep bevat een relatief klein aantal fraseologismen, waaronder we slechts één metafoor vinden - een man wordt altijd gezien als een lui liggende rustende man van hogere sociale status (de Tsjechische FE sedět jako pán - zitten als een heer en de Nederlandse FE in zijn bed liggen te rotten). Gezien het linguïstische beeld van de wereld worden beelden van ijver als positieve en luiheid als negatieve kenmerken gezien. Met betrekking tot het beeld van een vrouw binnen deze groep zijn luiheid altijd met negatieve en ijver met positieve gevoelens verbonden (de Nederlandse FE een bezige bij).

Dapperheid en lafheid behoren tot de eigenschappen die ook vaak binnen het corpus van de verzamelde fraseologismen te vinden zijn. Wat deze karaktertekens betreft, zijn ze in de meeste gevallen verbonden met de karaktertekening van een man (de Tsjechische FE odvážný jako lev-dapper als een leeuw). Moedigheid is vaak verbonden met het beeld van een leeuw of een leger. De FE gerelateerd aan het semantische beeld moedig zijn krijgen altijd een positieve connotatie. FE 
die betrekking hebben op het semantische beeld van lafheid krijgen een negatieve connotatie. Voor de beschrijving van het mannelijke gedrag wordt het beeld van een vrouw gebruikt (bijvoorbeeld de Tsjechische FE babské chováni - het gedrag van een oude vrouw). In dit geval wordt er over de expressiviteit gesproken. De fraseologismen in deze groep beschrijven enerzijds een man die laf is vanuit het perspectief van andere mensen en anderzijds gaat het om een stereotype dat zegt dat een vrouw meestal laf van aard is.

Nobelheid en ruwheid zijn ook eigenschappen die vaak voorkomen binnen het corpus van de verzamelde fraseologismen. Wat mannen betreft, vinden we de fraseologismen die ruw gedrag beschrijven (bijvoorbeeld de Nederlandse FE zo brutaal als een beul). Indien er positieve FE gevonden zijn, hebben ze betrekking tot de nobelheid, dus tot de sociale status van een man (de Tsjechische FE žit si jako pán-leven als een heer). Wat de vrouw en edel gedrag van mannen jegens haar betreft, worden deze FE beschouwd als een manifestatie van een positief mannelijk karakter en gedrag jegens vrouwen (bijvoorbeeld de Tsjechische FE zachovat se jako kavalir - zich gedragen als een cavalier).

Verwendheid en afhankelijkheid worden gevonden in fraseologismen die de invloed van ouders op hun kinderen beschrijven (bijvoorbeeld de Tsjechische FE držet se máminy sukně, dat ook in het Nederlands bestaat - aan moeders rokken blijven hangen). In de meeste gevallen zijn deze uitdrukkingen negatief.

Er bestaan ook fraseologismen die over een verlegen jongen/man praten. De eigenschappen van deze mannen worden beschreven door typisch vrouwelijke eigenschappen (de Tsjechischse FE ufñukaný jako stará bába - zeurderig als een oude vrouw of de Nederlandse FE daar is hij een kleine jongen bij). Deze eigenschappen zijn bijvoorbeeld: in tranen zijn of verlegen zijn.

Koppigheid, pietluttigheid, hebzucht, onbetrouwbaarheid, onverzorgdheid zijn ook karakteristieken die gevonden worden in onze corpus en meestal beschrijven ze mannen (bijv. de Tsjechische FE paličatý Janek - een koppige Janek). Overige positieve eigenschappen van mannen die we in ons corpus gevonden hebben zijn: betrouwbaarheid, ervaren zijn, hilarisch en grappig zijn (de Tsjechische FE veselý patron - een vrolijke patroon en het Nederlandse spreekwoord een vrolijke Frans). Al deze eigenschappen betreffen mensen in het algemeen, maar zijn verbonden met het mannelijke concept.

Wat de kijk op vrouwen en hun positieve eigeschappen betreft, zijn er slechts een paar fraseologismen gevonden. Meestal zijn vrouwen bescheiden (de Tsjechische FE milá jako holubička - lief als een duifje). Maar er bestaan veel fraseologismen die negatief over de vrouw en haar eigenschappen praten. Bazigheid, naïviteit, frivoliteit en boosheid (de Nederlandse FE een boze Griet) zijn de eigenschappen die het meest in ons corpus verschijnen. Als we deze groep fraseologismen beoordelen, vinden we dat er negatieve en positieve eigenschappen zowel over mannen als over vrouwen bestaan, maar dat er assymetrie in de taal bestaat, omdat negatieve eigenschappen die een man beschrijven vaak naar menselijke 
eigenschappen in het algemeen verwijzen (bijvoorbeeld de Tsjechische fraseologische eenheid ostř́lený kozák - een ervaren Kozak), terwijl de negatieve eigenschappen die vrouwen beschrijven meestal alléén naar vrouwen verwijzen (de Tsjechische fraseologische eenheid ženská jako san̆ - een vrouw als een draak) en niet naar mensen in het algemeen.

Fraseologismen die het karakter van mannen en vrouwen beschrijven, vormen de grootste semantische groep van FE. De algemeen positieve of algemeen negatieve evaluatie van mannen en vrouwen in termen van karaktereigenschappen komen het vaakst voor.

Fraseologismen van deze semantische groep suggereren dat de negatieve evaluatie van de mannelijke/vrouwelijke eigenschappen/karakter niet alleen op een vrouw gericht is (zoals bijna traditioneel verwacht wordt), maar ook op een man. Hier is ook het androcentrisme te zien: terwijl de positieve mannelijke eigenschappen heel frequent zijn, wordt een vrouw zelden of nooit positief beoordeeld. Gezien het stereotiepe beeld van vrouwen, worden babbelen en kletsen als typisch vrouwelijke karaktereigenschappen gezien (bijv. de Tsjechische FE mit hubu jak cikánka - mond hebben als een zigeunerin). Gezien het stereotiepe beeld van mannen dat door de taalkundige gegevens bevestigd wordt, zijn strijdbaarheid en vechtlust typisch mannelijke karaktereigenschappen (bijv. de Tsjechische FE bránit se jako lev - zich verdedigen als een leeuw). We hebben ook enkele m-FE geregistreerd die adel en grandeur in het gedrag van een man weerspiegelen. Breedsprakigheid, woordenstroom en zenuwachtigheid zijn eerder vrouwelijke dan mannelijke attributen. Sommige karaktertrekken karakteriseren mannen en vrouwen op een zeer vergelijkbare manier. Bijv. tussen de m-FE en f-FE die een man/vrouw beschrijven met betrekking tot hooghartigheid, is er slechts een klein kwantitatief verschil (bijv. de Tsjechische FE chodit jako baron/baronka - lopen als een baron/barones enz). Veel collocaties ondersteunen de bestaande stereotypen (Valdrová 2006) hoe een man en een vrouw zich in de samenleving zouden moeten gedragen: voor een vrouw zijn dat zachtheid, beleefdheid en mooi zijn (de Tsjechische FE krásná jako bohyně - knap als een godin enz.) enz. Voor mannen zijn dat kracht, vastberadenheid, dapperheid en charm tegenover een dame of anderen. De negatieve eigenschappen van een man zijn: hebzucht, onnatuurlijk gedrag, onbetrouwbaarheid, vijandigheid, slordigheid, goklust en koppigheid (bijv. de Nederlandse FE stinken als een bunzing). Vrouwelijke negatieve eigenschappen zijn: schertslust, frivoliteit, zachtheid, naïviteit en boosheid.

Vrijmoedigheid, betrouwbaarheid, ervaren zijn (bijv. de Tsjechische FE ostřilený kozák - een ervaren kozak) en humeurigheid (de Tsjechische FE - veselý patron - een vrolijke patroon - en het Nederlandse FE vrolijke Frans) worden gezien als positieve karaktertrekken in het geval van de stereotiepe aanpak van mannen en in het geval van de vrouwelijke eigenschappen zijn dat zachtmoedigheid, vriendelijkheid en bescheidenheid (bijv. de Tsjechische FE plachá jako lă̌/ laňka - verlegen als een jonge hinde). 
De data die we in ons corpus hebben verzameld, ondersteunen het stereotiepe beeld (Valdrová 2006) van man en vrouw in de maatschappij. Hieronder volgt de samenvattende weergave van de semantische groep Karakter van man en vrouw (de innerlijke eigenschappen ${ }^{6}$ ).

Tabel 1

\begin{tabular}{|c|c|c|}
\hline \multirow{2}{*}{ Geslacht } & \multicolumn{2}{|c|}{ Taal } \\
\cline { 2 - 3 } & Nederlands & Tsjechisch \\
\hline f. & 199 & 63 \\
\hline m. & 254 & 105 \\
\hline f., m. & 0 & 9 \\
\hline Totaal & 453 & 177 \\
\hline
\end{tabular}

Tabel 2

\begin{tabular}{|l|c|}
\hline \multicolumn{1}{|c|}{ Naam Subgroep } & $\begin{array}{c}\text { Aantal fraseologis- } \\
\text { men in de groep }\end{array}$ \\
\hline Een positieve/negatieve beoordeling & 282 \\
\hline Actief/passief karakter van man/vrouw & 92 \\
\hline Karaktereigenschappen typisch voor man/vrouw & 77 \\
\hline Spraakzaamheid/boosheid van man/vrouw & 39 \\
\hline Femininiteit/masculiniteit in karakter van man/vrouw & 18 \\
\hline Dapperheid/lafheid & 15 \\
\hline Nobelheid/ruwheid & 13 \\
\hline Hooghartigheid & 10 \\
\hline Overbezorgdheid/gebrek aan onafhankelijkheid & 7 \\
\hline Ijver/luiheid & 7 \\
\hline Andere eigenschappen & 70 \\
\hline
\end{tabular}

\section{Fraseologismen: Groep 2 - Fysieke en fysiologische eigenschappen, het uiterlijk van man en vrouw}

Deze groep telt het tweede grootste aantal FE in onze classificatie. Dit verwijst naar het feit dat deze kenmerken heel belangrijk zijn wat de karakteristieke ken-

${ }^{6}$ De eerste tabel bevat de vergelijking tussen de Tsjechische en de Nederlandse fraseologische eenheden met het oog op de gender. Om de tweede tabel overzichtelijker te maken, gaan we elke subgroep niet verder indelen op basis van gender specificatie. We melden het aantal Tsjechische fraseologische eenheden en de Nederlandse fraseologsiche eenheden samen. Dat geldt voor alle semantische groepen en subgroepen in dit artikel. 
merken van vrouwen en mannen betreft. Het belangrijkste criterium bij de beoordeling van het uiterlijk van een persoon (zowel mannen als vrouwen) zijn de aantrekkelijkheid en onaantrekkelijkheid. Binnen deze groep zijn er meer fraseologismen gevonden die een vrouw beschrijven. Het uiterlijk van vrouwen en mannen is ook in de beschrijving van het lichaam terug te vinden. De meeste FE met deze thematiek beschrijven een sterk en krachtig lichaam (bijvoorbeeld de Nederlandse FE een boom van een kerel, een beer van een vent enz.). Dit kenmerk van het uiterlijk wordt vaak geassocieerd met andere kenmerken, waarbij de vrouw zowel door haar uiterlijk als haar conditie wordt beschreven (de Tsjechische FE holka jako lusk - een meisje als een peul), terwijl de man alleen door zijn lichaamsbeeld wordt beschreven (bijv. de Tsjechische FE silný jako býk/ $d u b$ - sterk als een stier/eik enz.). Het fysieke uiterlijk van een persoon kan ook beschreven worden door lichaamsdelen als haar, baard en andere (de Tsjechische FE mit nohy jako strunky - benen als snaren hebben enz.). Deze FE evalueren een vrouw meestal in termen van haar seksuele aantrekkelijkheid in verband met de mannelijke visie op vrouwen.

De beschrijving van het uiterlijk van mannen en vrouwen is soms gevat in de beschrijving van hun kleding of in de beschrijving van de manier waarop ze zich kleden (bijv. de Tsjechische FE nastrojenálý jako nevěsta/ženich- opgedoft als een bruid/bruidegom). Kenmerkend voor mannen en vrouwen in dit geval is het niet goed gekleed zijn (bijv. de Tsjechische FE chodit jako čumploch - lopen als een slordige man), en dit wordt gezien als een negatief punt. De fraseologie registreert ook een benadering van de seksuele activiteit van mannen en vrouwen. Verhoogde activiteit en polygamie worden met betrekking tot vrouwen als negatieve verschijnselen gezien. Een vrouw is meestal terughoudend wat haar lusten betreft. De afwijking van deze "norm" is niet alleen de seksuele promiscuiteit, maar ook een beperkt seksleven (bijv. de FE een oude spinster zijn). Een seksueel actieve man wordt in vergelijking met een seksueel actieve vrouw gezien als braaf en veel FE in deze groep hebben een positieve connotatie. Een negatieve beoordeling wat mannen en hun seksuele activiteit betreft, wordt aangetroffen bij de beoordeling van mannen van hogere leeftijd en ook bij getrouwde mannen (bijv. de Nederlandse FE een oude bok lust nog wel een groen blaadje). Specifieke fysiologische toestanden zijn alleen terug te vinden in relatie tot de vrouw (de Tsjechische FE oloupit někoho o poctiviost - iemand op eerlijkheid veroveren en de Nederlandse FE een blode maagd, een late vrouw). Het gaat hier voornamelijk om zwangerschap en maagdelijkheid. Vrouwen en mannen kunnen ook worden beschreven door de manier van lopen of bewegen. Vanuit het globale perspectief op het thematische gebied van fysieke, fysiologische kenmerken en het uiterlijk van een man/vrouw kunnen we spreken van een volledige scheiding van specifieke kenmerken met betrekking tot het concept man en het concept vrouw. Het beeld van vrouwen is in de taal en FE vooral vertegenwoordigd wat de aantrekkelijkheid/onaantrekkelijkheid betreft, terwijl het beeld van mannen vooral fysieke eigenschappen betreft. Hieronder volgt de de samenvat- 
tende weergave van de semantische groep Fysieke en fysiologische eigenschappen, het uiterlijk van man en vrouw.

Tabel 3

\begin{tabular}{|c|c|c|}
\hline \multirow{2}{*}{ Geslacht } & \multicolumn{2}{|c|}{ Taal } \\
\cline { 2 - 3 } & Nederlands & Tsjechisch \\
\hline f. & 70 & 106 \\
\hline m. & 60 & 112 \\
\hline f., m. & 0 & 1 \\
\hline Totaal & 130 & 219 \\
\hline
\end{tabular}

Tabel 4

\begin{tabular}{|l|c|}
\hline \multicolumn{1}{|c|}{ Naam subgroep } & $\begin{array}{c}\text { Het aantal fraseo- } \\
\text { logismen in de groep }\end{array}$ \\
\hline Aantrekkelijkheid/onaantrekkelijkheid & 123 \\
\hline Leeftijd van man en vrouw & 78 \\
\hline Postuur van man en vrouw & 73 \\
\hline Seksuele activiteit van man en vrouw & 21 \\
\hline Specifieke fysiologische toestanden van een vrouw & 12 \\
\hline Bewegen & 10 \\
\hline Karakteristiek van man en vrouw door de lichaamsdelen & 7 \\
\hline Dood in de karakterisitek van man/vrouw & 3 \\
\hline Karakteristiek van man/vrouw op basis van de kleding & 2 \\
\hline Andere fysiologische eigenschappen van man/vrouw & 20 \\
\hline
\end{tabular}

\section{Fraseologismen: Groep 3 - Karakteriseren van mannen/ vrouwen door de eigenschappen van de tegenovergestelde sekse}

In deze groep is het aantal Tsjechische fraseologismen hoger dan het aantal Nederlandse. Met behulp van de eigenschappen van het andere geslacht kunnen zowel vrouwen als mannen beschreven worden (bijvoorbeeld de Tsjechische FE pověrčivý jako stará bába - bijgelovig zijn als een oude vrouw - praat over een man door de beschrijving van een oude vrouw). De dubbelzinnigheid van deze fraseologismen ligt in het verschil tussen de expliciete informatie inbegrepen in de betekenis van elke FE en de impliciete informatie in de interne vorm. Dat betekent dat de FE die het gedrag van mannen beschrijft, verwijst naar de ideeën over een vrouw, of vice versa. 
Hoewel de beschrijving van mannelijke en vrouwelijke eigenschappen vaak dezelfde is, kan er een verschil in de betekenis of connotatie zijn. Als voorbeeld nemen we de Tsjechische FE chodit jako slečinka - dribbelen als een juffertje overdreven gekleed en trots als een pauw lopen. In relatie tot het concept man en vrouw is deze FE negatief. Maar als het over een man gaat, is er ook een extra betekenis, die de expressiviteit aan deze FE verleent. De intensificatie van de betekenis onstaat doordat een bepaalde FE alleen met de karaktertrekken van één geslacht verbonden wordt en als we deze karaktertrekken voor het andere geslacht gaan gebruiken, krijgt deze FE meestal in de vorm van een intensificatie een expressieve betekenis (bijv. de Tsjechische FE mit ruce jako slečinka - handen hebben als een juffertje). Wat typisch is voor een vrouw, wordt beschouwd als abnormaal voor een man.

Het beschrijven van een persoon door de eigenschappen van het andere geslacht wordt gebruikt om de expressiviteit van de moedertaalspreker te benadrukken. Dit symboliseert de afwijking van de stereotiepe rolllen van mannen en vrouwen. Het gedrag van een individu dat niet overeen komt met de aanvaarde normen, wordt meestal veroordeeld. Een paar FE van dit type worden ook positief gezien. De volgende vraag dient zich aan: welke middelen worden gebruikt om de andere sekse te karakteriseren met behulp van de eigenschappen van de tegenovergestelde sekse? De f- en m-fraseologismen hebben een heel andere basis en er zijn meer FE voor de beschrijving van mannen dan voor die van vrouwen. Het mannelijke karakter dat door de vrouwelijke eigenschappen wordt beschreven is: benieuwd zijn, in tranen zijn, triest en verwend zijn, enz. (bijv. de Tsjechische FE červený jako panenka - rood als een poppetje, ufñukaný jako stará bába zeurderig als een oude vrouw enz.). Een vrouw die door mannelijke eigenschappen wordt beschreven, wordt meestal gezien als een sterke, soldateske vrouw die despotisch is (bijv. de Tsjechische FE ženská jako generál/grenadýr - een vrouw als een generaal/grenadier). Hieronder volgt de samenvattende weergave van de semantische groep Karakteriseren van mannen/vrouwen door de eigenschappen van de tegenovergestelde sekse.

Tabel 5

\begin{tabular}{|c|c|c|}
\hline \multirow{2}{*}{ Geslacht } & \multicolumn{2}{|c|}{ Taal } \\
\cline { 2 - 3 } & Nederlands & Tsjechisch \\
\hline f. & 1 & 6 \\
\hline m. & 0 & 16 \\
\hline Totaal & 1 & 22 \\
\hline
\end{tabular}




\section{Fraseologismen die gendercomponenten bevatten maar geen gender-semantiek hebben}

Het gendercomponent (de mannelijke of vrouwelijke naam) speelt in deze fraseologische eenheden een belangrijke rol maar heeft geen gender connotatie. We delen deze componenten in drie groepen in:

a) Fraseologismen uit antieke mythologie en mondiale letterkunde (bijvoorbeeld de FE de Amazone wil een Alexander, in Morpheus' armen liggen, het zwaard van Damocles enz.)

b) Fraseologismen van Bijbelse oorsprong (bijvoorbeeld de FE zo wijs als Salomo, zo rijk als Boaz, zo arm als Job enz.)

c) Fraseologismen van lokale oorsprong (bijvoorbeeld de FE een Jantje Contratie, een Jantje Secuur, Trijn en Griet deugen niet enz.)

De betekenis van het GK van namen van Bijbelse, antieke, literaire, lokale of mythologische figuren wordt gegeneraliseerd en hun kenmerken worden aan vrouwen of mannen toegewezen zonder dat ze iets met gendersemantiek hebben te maken. Als voorbeeld kiezen we voor het fraseologisme Achillova pata (de Achilleshiel) dat zowel een vrouw als een man kan beschrijven. In de loop der tijd wordt zo'n fraseologisme, met name de gendersemantiek, geneutraliseerd en krijgt het een algemene betekenis.

Veel FE van de voornoemde groepen worden op dezelfde manier gekarakteriseerd: hun gebruik met een mannelijke of vrouwelijke referent wordt niet beperkt door de betekenis of door de verbeelding. Deze uitdrukkingen hebben geen gendersemantiek, ondanks het feit dat ze mannelijke of vrouwelijke namen bevatten. De genderverhoudingen worden niet weerspiegeld, noch hun verbeelding noch hun etymologie. Als voorbeeld kiezen we voor de uitdrukking prít se jako Todar s Tadorou (letterlijk: redetwisten als Todar en Tador; Nederlands: leven als kat en hond). Deze uitdrukking die verwijst naar een man en een vrouw die na verloop van tijd een ruzieachtige relatie beginnen te hebben, geeft ons dus een ironisch beeld van de relatie tussen een vrouw en een man.

Verder komen we vaak uitdrukkingen tegen die een domme vrouw beschrijven (bijv. de Tsjechische FE to povídej staré Blažkové - vertel dat aan de oude Blazkova, žvanivý jako stará Káča - babbelziek als een oude Klaartje enz.). Deze fraseologische eenheden beschrijven de mens in het algemeen. De idiomen met GK die de naam van een familielid bevatten, komen ook heel vaak in ons corpus voor. Verder komt heel vaak het woord man voor als gendercomponent in een fraseologisme, terwijl de betekenis een mens in het algemeen is (bijv. het fraseologisme jednat jako jeden muž - als één man optreden).

De fraseologismen met GK, die geen gendersemantiek hebben, vormen een relatief grote groep, waarbij beide talen meer FE bevatten die een man karakteriseren. De gendercomponenten hebben niet altijd een relatie met het denotaat en 
de FE met deze componenten kunnen zowel op mannen als vrouwen betrekking hebben.

De oorzaken voor het verlies van gendersemantiek kunnen verschillend zijn. Het komt door het frequente gebruik van deze uitdrukkingen en generalisatie, door de betekenis of ook door de etymologie (Rejzek 1995). Heel vaak komt er in deze uitdrukkingen androcentrisme voor (als voorbeeld kiezen we voor de Tsjechische fraseologische eenheden otcovská hrouda - vaders aardklomp, otcovská střecha - vaders dak. In beide fraseologische eenheden bevat het adjectief beide ouders). Hieronder volgt de samenvattende weergave van de semantische groep Fraseologismen die gendercomponenten bevatten maar geen gendersemantiek hebben.

Tabel 6

\begin{tabular}{|c|c|c|}
\hline \multirow{2}{*}{ Geslacht } & \multicolumn{2}{|c|}{ Taal } \\
\cline { 2 - 3 } & Nederlands & Tsjechisch \\
\hline f-GC & 9 & 8 \\
\hline m-GC & 60 & 29 \\
\hline Totaal & 69 & 37 \\
\hline
\end{tabular}

\section{De problematiek van equivalentie in het Tsjechisch en het Nederlands}

Omdat de vergelijking van het fraseologische fonds van verschillende talen en het bepalen van de niveaus van equivalentie een heel moelijke taak is, is het essentieel om de mate van equivalentie te bepalen die wij kunnen gebruiken voor dit onderzoek teneinde de woordenlijst te kunnen samenstellen. Tot nu toe bestaat er geen overeenstemmende benadering tot de equivalentie in taal. Het is echter zeer belangrijk om een systeem van equivalentie te creëren, zowel in de praktijk - voor het leren van vreemde talen (in de lexicografie) - als op het theoretische niveau (bijv. voor de beschrijving van fraseologie van verschillende talen).

Voor dit onderzoek kiezen we voor de classificatie van equivalentie die František Čermák gebruikt (Čermák 1995). Deze classificatie wordt gebruikt bij het maken van de woordenlijst en voor de statistische evaluatie van fraseologismen die betrekking hebben op gender in beide talen - het Nederlands en het Tsjechisch. Voor dit systeem van equivalentie is de beeldspraak van de uitdrukkingen die we vergelijken het belangrijkste criterium, formele verschillen zijn minder belangrijk omdat het Tsjechisch en het Nederlands talen met een verschillende grammmaticale basis zijn. De verdeling van equivalentie is de volgende:

a) Volledige equivalentie

b) Gedeeltelijke equivalentie

c) Nul-equivalentie 
Het Nederlands wordt de brontaal voor onze woordenlijst van equivalenten. Net als František Čermák kiezen wij voor een indeling inclusief de groep van volledige equivalenten. Onder volledige equivalenten begrijpen we uitdrukkingen die op het formele en semantische niveau identiek zijn, inclusief kleine verschillen (bijvoorbeeld wat het aantal componenten en/of het morfologische onderscheid van componenten betreft - de Tsjechische fraseologische eenheid být pod pantoflem en de Nederlandse fraseologische eenheid onder de pantoffel zitten).

De gedeeltelijke equivalenten zijn de uitdrukkingen die dezelfde of vergelijkbare beelden en een soortgelijke of verschillende structuur hebben. Deze groep bestaat uit uitdrukkingen die een andere metaforische basis hebben, maar de metaforische overdracht vindt plaats op basis van dezelfde symptomen. Deze groep is zeer breed en omvat FE van zeer diverse aard (bijvoorbeeld de fraseologische eenheden een dame van lichte zeden en lehká žena - een makkelijke vrouw).

De laatste groep bevat de zogenaamde zero (nul)-equivalentie waar bepaalde FE alleen in één van de twee talen die wij onderzoeken gevonden worden. Deze FE kunnen echter wel equivalenten hebben in andere talen.

Het woordenboek van de geselecteerde fraseologismen met gendersemantiek en gendercomponenten toont de nabijheid of afstand van fraseologische analoog in beide talen. Tegelijkertijd worden er mogelijke vertalingen van FE voorgesteld, alsmede overeenkomsten en verschillen in metaforen en vergelijkingen die in beide talen worden gebruikt voor het uiten van dezelfde betekenis. Deze aanpak is essentieel voor dit onderzoek, samen met het leggen van de nadruk op de monitoring van culturele informatie in taal ${ }^{7}$.

\section{De uitvoering van de equivalentie - contrastieve analyse}

De opzet van de contrastieve analyse is in de eerste plaats om een antwoord te krijgen op de vraag welke kwantitatieve en kwalitatieve equivalentieverhoudingen er bestaan tussen de geëxcerpeerde Tsjechische fraseologische eenheden met het concept gender en hun Nederlandse pendanten. Daarnaast was het doel van deze analyse om de rol van gender in taal te onderzoeken en de stereotypen in taal die met gender verbonden zijn te tonen. Als we de hoeveelheid pendanten in het Tsjechisch en het Nederlands analyseren, zijn er theoretisch 3 kwantitatieve equivalentiegroepen te onderscheiden:

a) Één Nederlandse fraseologische eenheid heeft precies één Tsjechisch equivalent

b) Één Nederlandse eenheid heeft enkele synonieme equivalenten in het Tsjechisch

${ }^{7}$ De culturele informatie in taal verwijst naar de culturele erfenis en tradities van een maatschappij (die al jarenlang bestaan) en vaak verandert dankzij de maatschappelijke veranderingen. 
c) Één fraseologische éénheid in het Nederlands heeft geen Tsjechisch equivalent

In de analyse letten we op de betekenis van beeldspraak van fraseologismen in beide talen. De primaire criteria zijn de semantiek en metaforiek. Maar we letten ook op de parallellen in hun lexica, grammaticale structuren en stylistische middelen. Wat ook opvallend is, is dat de fraseologische eenheden in het Nederlands meestal de vorm van een zin hebben. De Tsjechische fraseologische eenheden bestaan daarentegen uit twee of drie woorden. Daarom bestaat er dus een klein percentage fraseologismen dat totaal equivalent is. Hieronder zijn de verzamelde data te vinden wat de equivalentie in beide talen ten opzichte van gendergebonden fraseologismen betreft.

Tabel 7

\begin{tabular}{|c|c|c|}
\hline \multirow{2}{*}{ Niveau equivalentie } & \multicolumn{2}{|c|}{ Taal } \\
\cline { 2 - 3 } & Nederlands & Tsjechisch \\
\hline Totale equivalentie & $7(1,2 \%)$ & $7(1,3 \%)$ \\
\hline Gedeeltelijke equivalentie & $194(33,2 \%)$ & $194(35,4 \%)$ \\
\hline Nul equivalentie & $383(65,6 \%)$ & $347(63,3 \%)$ \\
\hline
\end{tabular}

\begin{tabular}{|c|c|}
\hline \multicolumn{2}{|c|}{ Het totale aantal fraseologismen } \\
\hline Nederlands & Tsjechisch \\
584 & 548 \\
\hline
\end{tabular}

\section{De uitslag van het contrastieve onderzoek}

Samenvattend kunnen we concluderen dat de derde groep, de nul-equivalentie, absoluut het grootst is. Veel uitdrukkingen hebben een andere metaforische basis, maar de metaforische overdracht vindt op basis van hetzelfde attribuut plaats (bijvoorbeeld de Nederlandse fraseologische eenheid een zware jongen en de Tsjechische fraseologische eenheid ostrý hoch-een scherpe jongen). Dat betekent dat de groep van de fraseologische eenheden die binnen het kader van de gedeeltelijke equivalentie vallen, het tweede grootste aantal fraseologismen bevat.

\section{Conclusie}

De bedoeling van deze contrastieve analyse was om de Nederlandse tegenhangers van de Tsjechische fraseologische eenheden vast te stellen. We hebben de overeenkomsten op het gebied van de betekenis en beeldspraak gezocht. De overeenkomsten wat betreft de stylistische middelen, lexicale middelen en grammaticale 
structuren waren minder belangrijk (zie p. 137). Binnen dit onderzoek werd de hoeveelheid gender verwante fraseologismen in groepen ingedeeld op basis van de meest voorkomende associaties/symptomen wat het stereotiepe beeld van mannen en vrouwen betreft. Het aantal geselecteerde fraseologismen met betrekking tot het concept gender hielp ons om collectieve ideeën van moedertaalsprekers samen te vatten met betrekking tot de rol van mannen en vrouwen in de maatschappij, maar ook met betrekking tot de sociale veranderingen in de maatschappij en veranderingen in de sociale status van mannen en vrouwen in de samenleving. Gebaseerd op de tradities, komt in elke geselecteerde groep het concept man en het concept vrouw met verschillende frequentie voor, gebaseerd op de gender stereotypes die in onze samenleving vastgesteld zijn.

We kunnen uit dit onderzoek concluderen dat er in beide talen meer fraseologismen over mannen bestaan en dat er meer FE bestaan die negatief jegens vrouwen zijn. Het Nederlands is negatiever met betrekking tot beide geslachten dan het Tsjechisch. Er bestaan meer fraseologismen die over het karakter van mannen en vrouwen gaan dan fraseologismen die het uiterlijk of fysieke eigenschappen van mannen en vrouwen beschrijven in beide talen. We kunnen ook concluderen dat er meer stereotypen over mannen bestaan dan over vrouwen. Maar het verschil is klein. (Er werden 445 fraseologische eenheden gevonden die een vrouw beschrijven en 447 fraseologische eenheden die een man beschrijven.)

De contrastieve analyse wijst op een klein aantal totale overeenkomsten tussen beide talen. De overeenkomsten zijn meestal in de beeldspraak en semantiek te vinden en daarom is het aantal gedeeltelijke equivalenten het hoogst, omdat beide talen niet lexicaal, morfologisch en syntactisch verwant zijn ${ }^{8}$.

\section{Resultaten}

Hieronder vinden we de tabel van fraseologismen met het niveau van equivalentie (de volledige of gedeeltelijke equivalentie).

Lijst van fraseologische eenheden met de volledige $(=)$ en gedeeltelijke equivalentie $(\approx)$

\begin{tabular}{|l|l|}
\hline \multicolumn{1}{|c|}{ Nederlands } & \multicolumn{1}{|c|}{ Equivalent in het Tsjechisch $^{3}$} \\
\hline een nieuwsgierig Aagje & zvědavá Eva $\approx[$ een nieuwsgierige Eva] \\
\hline & $\begin{array}{l}\text { zvědavý jako stará bába } \approx[\text { [nieuwsgierig als } \\
\text { een oude vrouw] }\end{array}$ \\
\hline & $\begin{array}{l}\text { zvědavý jako stará Blažková } \approx[\text { nieuwsgierig } \\
\text { als de oude Blazkova] }\end{array}$ \\
\hline $\begin{array}{l}\text { al draagt een aap een gouden ring, het is en } \\
\text { blijft een lelijk ding }\end{array}$ & $\begin{array}{l}\text { být šeredná jako opice } \approx[\text { lelijk als een aap] } \\
\text { být ošklivý jako opice } \approx[\text { lelijk als een aap] }\end{array}$ \\
\hline
\end{tabular}

8 Het Nederlands is een analytische taal, het Tsjechisch is een synthetische taal. 


\begin{tabular}{|c|c|}
\hline \multirow[t]{2}{*}{ een aap van een jongen } & ostrý hoch $\approx$ [een scherpe jongen] \\
\hline & hromský chlap $\approx$ [een man van donder] \\
\hline \multirow[t]{3}{*}{ zo trots als een aap/pauw } & $\begin{array}{l}\text { chodit/nést se/vykračovat si jako pávice } \approx[\text { lo- } \\
\text { pen als een pauw }]\end{array}$ \\
\hline & $\begin{array}{l}\text { pyšná jako pávice } \approx \text { [trots als een pauwen- } \\
\text { vrouwtje] }\end{array}$ \\
\hline & pyšný jako páv $\approx$ [trots als een pauw] \\
\hline zo stom als het achtereind van een varken/koe & hloupý jako osel $\approx[$ dom als een ezel $]$ \\
\hline in adamskostuum & nahý jako Adam $\approx$ [naakt als Adam] \\
\hline het in zijn broek doen & být jako trasořitka $\approx$ [een kwikstaart zijn] \\
\hline onder de pantoffel zitten & být pod pantoflem $\approx$ [onder de pantoffel zijn] \\
\hline \multirow[t]{2}{*}{ aan moeders rokken blijven hangen } & $\begin{array}{l}\text { držet se máminy sukně } \approx \text { [aan moeders rok } \\
\text { vasthouden] }\end{array}$ \\
\hline & $\begin{array}{l}\text { držet se někoho za sukni } \approx \text { [vasthouden aan } \\
\text { iemands rok] }\end{array}$ \\
\hline de broek aan hebben & chodit $\mathrm{v}$ kalhotách $\approx[$ lopen in een broek] \\
\hline \multirow[t]{2}{*}{ aan Bacchus offeren } & pít jako Dán $\approx$ [drinken als een Deen] \\
\hline & pít jako námořník $\approx$ [drinken als een zeeman] \\
\hline \multirow[t]{3}{*}{ een beer van een vent } & být silný jako medvěd $\approx$ [sterk als een beer $]$ \\
\hline & být silný jako lev $\approx$ [sterk als een leeuw] \\
\hline & být silný jako býk $\approx$ [sterk als een stier] \\
\hline \multirow[t]{4}{*}{ een geile beer, een geile bok } & být na ženské $\approx$ [op vrouwen vallen] \\
\hline & chodit za děvčaty $\approx$ [lopen naar meisjes] \\
\hline & $\begin{array}{l}\text { prohánět každou sukni } \approx \text { [achter alle rokken } \\
\text { aan jagen] }\end{array}$ \\
\hline & $\begin{array}{l}\text { mlsný starý kocour } \approx \text { [een pietluttige oude } \\
\text { kater] }\end{array}$ \\
\hline \multirow[t]{2}{*}{ een ongelikte beer } & $\begin{array}{l}\text { chovat se jako medvěd } \approx \text { [zich gedragen als } \\
\text { een beer] }\end{array}$ \\
\hline & jako slon $\approx$ [zich gedragen als een olifant] \\
\hline \multirow[t]{7}{*}{ sterk als een Turk } & silný jako Bivoj $\approx$ [sterk als Bivoj] \\
\hline & silný jako Herkules $\approx$ [sterk als Herkules] \\
\hline & silný jako býk $\approx$ [ sterk als een stier] \\
\hline & silný jako dub $\approx[$ sterk als een eik] \\
\hline & silný jako lev $\approx$ [ sterk als een leeuw] \\
\hline & silný jako medvěd $\approx$ [ sterk als een beer] \\
\hline & silný jako tur $\approx[$ sterk als een rund] \\
\hline drinken als een tempelier & pít jak Dán $\approx$ [drinken als een Deen] \\
\hline
\end{tabular}




\begin{tabular}{|c|c|}
\hline & pít jak námořník $\approx$ [drinken als een zeeman] \\
\hline rijke stinkerd & těžký pracháč $\approx$ [een zware rijkaard] \\
\hline \multirow[t]{3}{*}{ een boer op klompen } & hloupý Honza $\approx$ [een domme Honza] \\
\hline & hloupý Janek $\approx$ [een domme Janek] \\
\hline & hloupý jak osel $\approx$ [dom als een ezel] \\
\hline \multirow[t]{3}{*}{ lachen als een boer die kiespijn heeft } & $\begin{array}{l}\text { smát se jak Filip na jelito } \approx[\text { lachen als Filip op } \\
\text { een bloedworst }]\end{array}$ \\
\hline & smát se jak Honza $\approx$ [lachen als Honza] \\
\hline & smát se jak Kuba $\approx$ [lachen als Kuba] \\
\hline \multirow[t]{3}{*}{ ik ben ook maar een eenvoudige boerenlul } & hloupý Honza $\approx$ [een domme Honza] \\
\hline & hloupý Janek $\approx$ [een domme Janek] \\
\hline & hloupý jako osel $\approx[$ dom als een ezel $]$ \\
\hline \multirow[t]{3}{*}{ een oude bok lust nog wel een groen blaadje } & starý kocour $\approx$ [een oude kater] \\
\hline & stará liška $\approx$ [een oude vos] \\
\hline & starý kozel $\approx$ [een oude bok] \\
\hline \multirow[t]{3}{*}{ een bonk van een kerel } & kluk jak buk $\approx$ [een jongen als een beuk] \\
\hline & chlap jak hora $\approx[$ een jongen als een berg] \\
\hline & $\begin{array}{l}\text { chlap jak pořízek } \approx \text { [een jongen als een dik- } \\
\text { kertje] }\end{array}$ \\
\hline \multirow[t]{2}{*}{ een boom van een kerel } & $\begin{array}{l}\text { urostý jako topol } \approx \text { [goed gevormd als een } \\
\text { populier] }\end{array}$ \\
\hline & silný jako dub $\approx$ [sterk als een eik] \\
\hline \multirow[t]{3}{*}{ hij is niets dan vel over been } & $\begin{array}{l}\text { hubený jako drožkářská kobyla } \approx \text { [mager als } \\
\text { een koetsmerrie] }\end{array}$ \\
\hline & hubený jako lunt $\approx$ [mager als bot] \\
\hline & hubený jako koza $\approx$ [mager als een geit] \\
\hline een te grote broek hebben & $\begin{array}{l}\text { namyšlený jako páv/pávice } \approx \text { [trots als een } \\
\text { pauw/pauwenvrouwtje] }\end{array}$ \\
\hline \multirow[t]{2}{*}{ stinken als een bunzing } & smrdět jako kozel $\approx[$ stinken als een bok] \\
\hline & smrdět jako Herodes $\approx$ [stinken als Herodes] \\
\hline \multirow[t]{2}{*}{ hij heeft het buskruit niet uitgevonden } & hloupý Honza $\approx$ [een domme Honza] \\
\hline & hloupý Janek $\approx$ [een domme Janek] \\
\hline \multirow[t]{2}{*}{ zo rijk als Croesus zijn } & bohatý jako Krésus $\approx$ [rijk als Croesus] \\
\hline & bohatý jako Rotschild $\approx$ [rijk als Rotschild] \\
\hline \multirow[t]{3}{*}{ een dame van lichte zeden } & lehká žena $\approx$ [een lichte vrouw] \\
\hline & prodejná žena $\approx$ [een vrouw te koop] \\
\hline & povětrná žena $\approx$ [een lichtzinnige vrouw] \\
\hline
\end{tabular}




\begin{tabular}{|c|c|}
\hline \multirow[t]{2}{*}{ een dooie diender } & nudný patron $\approx$ [een saaie patroon] \\
\hline & suchý patron $\approx$ [een droge patroon] \\
\hline \multirow[t]{2}{*}{ dronken als een dragonder/Maleier } & opilý jako indián $\approx$ [dronken als een Indiaan] \\
\hline & $\begin{array}{l}\text { zmalovat se jako indián } \approx \text { [zich overdreven } \\
\text { schminken als een Indiaan] }\end{array}$ \\
\hline zo duf als een konijn & hloupý jak osel $\approx$ [dom als een ezel] \\
\hline de duivel is in hem gevaren & $\begin{array}{l}\text { čertův chlapík } \approx \text { [een mannetje van een dui- } \\
\text { vel] }\end{array}$ \\
\hline zo dom als een ezel & hloupý jako osel $\approx$ [dom als een ezel] \\
\hline een vrolijke Frans & veselý patron $\approx$ [een vrolijke patroon] \\
\hline \multirow[t]{3}{*}{ een wandelend geraamte } & hubený jako lunt $\approx$ [mager als bot] \\
\hline & $\begin{array}{l}\text { hubený jako drožkářská kobyla } \approx \text { [mager als } \\
\text { een koetsmerrie] }\end{array}$ \\
\hline & hubený jako koza $\approx$ [mager als een geit] \\
\hline een groene weduwe & slaměnná vdova $\approx$ [een weduwe van stro] \\
\hline \multirow[t]{2}{*}{ de heer des huizes } & pán situace $\approx$ [de heer van de situatie] \\
\hline & být pánem $\approx$ [een heer zijn] \\
\hline Jan Boezeroen & muž práce $\approx$ [een werkende man] \\
\hline Jan Kordaat & čupr kluk $\approx$ [een knappe jongen] \\
\hline \multirow[t]{2}{*}{ Jan Lul } & mizera chlap $\approx$ [een ellendige kerel] \\
\hline & pacholek mizerná $\approx$ [een ellendige knecht] \\
\hline een zware jongen & ostrý hoch $\approx$ [een scherpe jongen] \\
\hline jongen van Hans de Witt & zlatý chlap $\approx$ [een man van goud] \\
\hline \multirow[t]{2}{*}{ een Joris Goedbloed } & $\begin{array}{l}\text { plachý jak panenka } \approx \text { [verlegen als een pop- } \\
\text { petje] }\end{array}$ \\
\hline & $\begin{array}{l}\text { plachý jak třasořitka } \approx \text { [verlegen als een kwik- } \\
\text { staart] }\end{array}$ \\
\hline een kwal van een vent & $\begin{array}{l}\text { plesnivý dědek } \approx \text { [een beschimmelde oude } \\
\text { man] }\end{array}$ \\
\hline \multirow[t]{7}{*}{ een meisje van plezier } & pouliční holka $\approx$ [een straatmeisje] \\
\hline & holka $\mathrm{z}$ ulice $\approx$ [een meisje van de straat] \\
\hline & padlá dívka $\approx$ [een gevallen meisje] \\
\hline & tuzexová slečna $\approx$ [een meisje uit Tuzex] \\
\hline & $\begin{array}{l}\text { lehká žena/ženská/ženština } \approx \text { [een makkelijke } \\
\text { vrouw/wijf] }\end{array}$ \\
\hline & $\begin{array}{l}\text { povětrná žena/ženská/ženština } \approx \text { [een lich- } \\
\text { tekooi] }\end{array}$ \\
\hline & $\begin{array}{l}\text { prodejná žena/ženská/ženština } \approx \text { [een vrouw } \\
\text { te koop] }\end{array}$ \\
\hline
\end{tabular}




\begin{tabular}{|c|c|}
\hline ome Jan & obecní vůl $\approx$ [een gemeente ezel] \\
\hline een oude sok & starý paprika $\approx$ [een oude paprika] \\
\hline een lekker stuk & $\begin{array}{l}\text { děvče jako broskev } \approx[\text { een meisje als een per- } \\
\text { zik] }\end{array}$ \\
\hline \multirow[t]{2}{*}{ hij is niets dan vel en botten } & hubený jako koza $\approx$ [mager als een geit] \\
\hline & hubený jako lunt $\approx$ [mager als bot] \\
\hline \multirow[t]{2}{*}{ het vet zit hem niet in de weg } & hubený jako koza $\approx$ [mager als een geit] \\
\hline & hubený jako lunt $\approx$ [mager als bot] \\
\hline \multirow[t]{2}{*}{ schelden als een viswijf } & $\begin{array}{l}\text { nadávat jako kanonýr } \approx \text { [schelden als een ka- } \\
\text { nonnier] }\end{array}$ \\
\hline & klít jako dáběl $\approx$ [schelden als een duivel] \\
\hline een oude vos & stará liška $\approx$ [een oude vos] \\
\hline een Don Juan & $\begin{array}{l}\text { dobyvatel ženských srdcí } \approx \text { [een veroveraar } \\
\text { van vrouwenharten] }\end{array}$ \\
\hline hij weet van de hoed en de rand & Děd Vševěd $\approx$ [grootvader allerwetend] \\
\hline \multirow[t]{2}{*}{ Jan de Wasser } & mizera chlap $\approx$ [een ellendige kerel] \\
\hline & pacholek mizerná $\approx$ [een ellendige knecht] \\
\hline \multirow[t]{2}{*}{ een kerel als Kas } & silný jako Herkules $\approx$ [sterk als Herkules] \\
\hline & silný jako Bivoj $\approx$ [sterk als Bivoj] \\
\hline \multirow[t]{2}{*}{ een sterke knevel } & jako hrom $\approx[$ als een donder $]$ \\
\hline & Hromotluk $\approx[$ bonk van een kerel] \\
\hline \multirow[t]{2}{*}{ zo rijk als Boaz } & bohatý jako Krésus $\approx$ [rijk als Croesus] \\
\hline & bohatý jako Rotshild $\approx$ [rijk als Rotshild] \\
\hline een tang van een wijf & ještěrčí jazyk $\approx$ [tong van een hagedis] \\
\hline een ongelovige Thomas & nevěřící Tomáš $\approx$ [ongelovige Tomas] \\
\hline een boze Griet & ženská jako saň $\approx$ [een vrouw als een draak] \\
\hline \multirow[t]{2}{*}{ een dienende Martha } & ženská jako saň $\approx$ [een wijf als een draak] \\
\hline & $\begin{array}{l}\text { ženská jako britva } \approx \text { [een vrouw als een } \\
\text { scheermes] }\end{array}$ \\
\hline \multirow[t]{2}{*}{ een gekke Gerrit } & splašený Janek $\approx$ [een onbesuisde Janek] \\
\hline & potrhlý Janek $\approx$ [een gekke Janek] \\
\hline \multirow[t]{3}{*}{ een gekke Trien } & káča pitomá $\approx$ [een dolle Trein] \\
\hline & hloupá náná $\approx$ [een domme Anna] \\
\hline & hloupá husa $\approx$ [een domme gans] \\
\hline \multirow[t]{2}{*}{ het is een Goliath } & silný jako Bivoj $\approx$ [sterk als Bivoj] \\
\hline & silný jako Herkules $\approx$ [sterk als Herkules] \\
\hline een ijzeren Hein & $\begin{array}{l}\text { chlap že by skály mohl lámat } \approx \text { [een jongen } \\
\text { die rotsen kon breken] }\end{array}$ \\
\hline
\end{tabular}




\begin{tabular}{|c|c|}
\hline een houten Klaas & nudný patron $\approx$ [een saaie patroon] \\
\hline & suchý patron $\approx$ [een droge patroon] \\
\hline een Jan-hen & být pod pantoflem $\approx$ [onder de pantoffel zijn] \\
\hline \multirow[t]{2}{*}{ een Jan Onbenul } & hloupý Janek $\approx$ [een domme Janek] \\
\hline & hloupý Honza $\approx$ [een domme Honza] \\
\hline een toffe jongen & kluk miliónská $\approx$ [een miljoenenjongen] \\
\hline een kerel als een boom & silný jako dub $\approx[$ sterk als een eik $]$ \\
\hline \multirow[t]{2}{*}{ een kranige kerel } & povedený chlapík $\approx$ [een slimme vent] \\
\hline & podařený chlapík $\approx$ [een enige vent] \\
\hline hij is zo levendig als het vogeltje dat koe heet & $\begin{array}{l}\text { válet se někde jako kanec } \approx \text { [rollen/liggen als } \\
\text { een everzwijn] }\end{array}$ \\
\hline \multirow[t]{2}{*}{ een kraan van een jonge } & povedený chlapík $\approx$ [een slimme vent] \\
\hline & podařený chlapík $\approx$ [een enig vent] \\
\hline kwajongen & vykutálený chlapík $\approx$ [een sluwe vent] \\
\hline hij heeft een laadstok doorgeslikt & $\begin{array}{l}\text { být jako žehlící prkno } \approx \text { [als een strijkplank } \\
\text { zijn] }\end{array}$ \\
\hline \multirow[t]{2}{*}{ het is een wijze man, die maar ramen kan } & otec myšlenky $\approx[$ de vader van het idee $]$ \\
\hline & děd Vševěd $\approx$ [grootvader allerwetend] \\
\hline een statige matrone & $\begin{array}{l}\text { ženská jako grenadýr } \approx \text { [een vrouw als een } \\
\text { grenadier] }\end{array}$ \\
\hline \multirow[t]{2}{*}{ een meisje van drie kruisjes } & $\begin{array}{l}\text { ujel jí poslední vlak } \approx \text { [zij heeft de laatste trein } \\
\text { gemist] }\end{array}$ \\
\hline & stará můra $\approx$ [een oude mot] \\
\hline \multirow[t]{3}{*}{ hij heeft zijn mond bij zich } & $\begin{array}{l}\text { být ukecaný jako stará bába } \approx \text { [kletserig zijn } \\
\text { als een oude vrouw] }\end{array}$ \\
\hline & $\begin{array}{l}\text { mít hubu jak šlejfířka } \approx \text { [een mond hebben als } \\
\text { een slijper] }\end{array}$ \\
\hline & $\begin{array}{l}\text { mít hubu jak cikánka } \approx \text { een mond hebben als } \\
\text { een zigeunerin] }\end{array}$ \\
\hline je bent een mooie & pěkný jako panáček $\approx[$ knap als een mannetje $]$ \\
\hline \multirow[t]{3}{*}{ oud en stam en nog geen man } & zralý na ženění $\approx$ [volwassen om te trouwen] \\
\hline & starý paprika $\approx[$ een oude paprika] \\
\hline & věčný mladík $\approx$ [een eeuwige jonge man] \\
\hline \multirow[t]{2}{*}{ een roes aan hebben } & pít jako Dán $\approx$ [drinken als een Deen] \\
\hline & pít jako námořník $\approx$ [drinken als een zeeman] \\
\hline in iedere stad een andere schat & $\begin{array}{l}\text { honit se za každou sukn í } \approx \text { [ achter alle rokken } \\
\text { aanjagen] }\end{array}$ \\
\hline een type van een kerel & divný pták/patron $\approx$ [een rare vogel/patroon] \\
\hline
\end{tabular}




\begin{tabular}{|c|c|}
\hline & $\begin{array}{l}\text { podezřelý pták/patron } \approx \text { [een verdachte vogel/ } \\
\text { patroon] }\end{array}$ \\
\hline zo vals als Judas & Jidášův polibek $\approx$ [een kus van Judas] \\
\hline \multirow[t]{2}{*}{ in blijde verwachting zijn } & být $\mathrm{v}$ tom $\approx$ [zwanger zijn] \\
\hline & být $\mathrm{v}$ jiném stavu $\approx$ [in een andere staat zijn] \\
\hline een kreng van een wijf & stará čarodejnice $\approx$ [een oude heks] \\
\hline zwanger gaan aan iets & tlustý jak vepřr $\approx$ [vet als een varken] \\
\hline \multirow[t]{2}{*}{ een hoer als een paard } & stará škatule $\approx[$ een oude doos $]$ \\
\hline & veselá v rozkroku $\approx$ [vrolijk in het kruis] \\
\hline de man woont in het vrouwenstraatje & chodit $\mathrm{v}$ kalhotách $\approx$ [in broeken lopen] \\
\hline $\begin{array}{l}\text { baard, broek en beurs dat zijn de drie b's van } \\
\text { de man die de vrouw mijden moet }\end{array}$ & má všech pět $\mathrm{p} \approx$ [alle vijf p's hebben] \\
\hline als vrouw wordt man gaat het slecht & ženská jako chlap $\approx$ [een vrouw als man] \\
\hline een schoon vrouwtje en wijn op de dis & lev salónů $\approx$ [de leeuw van de salons] \\
\hline \multirow[t]{2}{*}{ als de hen kwaad is, ontziet ze de haan niet } & ženská jako saň $\approx$ [een wijf als een draak ] \\
\hline & $\begin{array}{l}\text { ženská jako britva } \approx \text { [een vrouw als een } \\
\text { scheermes ] }\end{array}$ \\
\hline $\begin{array}{l}\text { als de hennen beginnen te kraaien, moet men } \\
\text { ze de nek omdraaien }\end{array}$ & $\begin{array}{l}\text { držet se vařečky } \approx \text { [vasthouden aan de houten } \\
\text { lepel] }\end{array}$ \\
\hline $\begin{array}{l}\text { de vrouw is toch het hart, dat hij niet missen } \\
\text { kan }\end{array}$ & $\begin{array}{l}\text { dáma něčího srdce } \approx \text { [een dame van iemands } \\
\text { hart] }\end{array}$ \\
\hline $\begin{array}{l}\text { een degelijke huisvrouw moet zorgen voor vijf } \\
\text { k's: kinderen, kamer, keueken, kolen, kelder } \\
\text { en kleren }\end{array}$ & $\begin{array}{l}\text { mít všech pět } \mathrm{p} / \text { starostlivá matka/kvočna } \approx \\
\text { [alle vijf p's hebben/een zorgvuldige moeder/ } \\
\text { kloek] }\end{array}$ \\
\hline \multirow{2}{*}{$\begin{array}{l}\text { een goede huisvrouw zingt ook tussen de la- } \\
\text { kens }\end{array}$} & domácí put'ka $\approx$ [een huisluilak] \\
\hline & taková kuchyňka $\approx$ [een keukenprinses] \\
\hline \multirow[t]{2}{*}{ oude katten lusten ook melk } & starý kocour $\approx$ [een oude kater] \\
\hline & starý paprika $\approx$ [een oude paprika] \\
\hline $\begin{array}{l}\text { de vrouw draagt zelden haar schoonste sieraad: } \\
\text { het zwijgen }\end{array}$ & $\begin{array}{l}\text { mít hubu jak šlejfířka } \approx \text { [mond hebben als een } \\
\text { scheermes] }\end{array}$ \\
\hline \multirow[t]{4}{*}{ een mooie vrouw is een hemel voor ogen } & krásná jako madona $\approx[$ knap als een madonna $]$ \\
\hline & krásná jako růže $\approx$ [mooi als een roos] \\
\hline & krásná jako víla $\approx[$ mooi als een fee $]$ \\
\hline & $\begin{array}{l}\text { krásná jako princezna } \approx[\text { knap als een princes }] \\
\text { krásná jako bohyně } \approx[\text { knap als een godin }]\end{array}$ \\
\hline $\begin{array}{l}\text { een verstandige vrouw weet wel dat de man de } \\
\text { broek aan moet houden }\end{array}$ & nosit kalhoty $\approx[$ een broek dragen $]$ \\
\hline rijke vrouwen, arme kinderen & krkavčí matka $\approx$ [een ravenmoeder] \\
\hline
\end{tabular}




\section{Corpusbronnen}

Čermák, F. Hnrčířová, Z. Nizozemsko-český slovnik / Nederlands-Tsjechisch woordenboek. Praha: Leda 1997.

Čermák, F. Slovnik české frazeologie a idiomatiky. Praha: Karolinum, 2009.

Čermák, F. Holub, J., Blatná, R., Kopřivová, M. Slovnik české frazeologie a idiomatiky. Výrazy větné. Praha: Leda, 2009.

Dale, J.H. van. Nieuw groot woordenboek der Nederlandes taal. Gravenhage: M. Nijhoff, 1950.

Groot de, H. Van Dale idioomwoordenboek. Amsterdam/Brussel: The Readers Digest uitgeverij, 1999.

Huizinga, A. Spreekwoorden en gezegden. Amsterdam: Tirion Uitgevers, 1994.

Stoett, F.A. Nederlandse sprekwoorden en gezegden. Zutphen: b.v. W.J. Thieme redactie, 1981.

Ter Laan, K., Heidt, A.M., van Geest, T., van den Berg, K. Nederlandse spreekwoorden, spreuken en zegswijzen. 's-Gravenhage: Het Spectrum, 2003.

Verbeek, G. Gevleugelde woorden, spreekwoorden zegwijzen en andere vormen van wijsheidliteratuur. Leuven: Davidsfonds uitgeverij, 2013.

\section{Bibliografie}

Brainerd, B. Mathematical Linguistics and Automatic Language Processing. New York: American Elsevier Publishing Company, 1971.

Coates, J. Language and gender: a reader. Oxford: Oxford University Press, 2011.

Čechová, M. Dynamika frazeologie. Naše řeč 76. 1986, p. 178-186.

Čermák, F. Překladová lexikografie. In: Blatná R. et al.: Manuál lexikografie H\&H 1995.

Čermák, F. Základy lingvistické metodologie: Nástin hlavních principů na pozadí obecné teorie vědy. Praha: Karolinum, 1994.

Čermák, F. Frazeologie a idiomatika česká a obecná. Praha: Karolinum, 2007.

Čmejrková, S. Rod v jazyce a komunikaci: specifika češtiny. Slovo a slovesnost. 2002, roč. 63, č. 4, p. 263-286.

Čmejrková, S. Jazyk pro druhé pohlaví. In: Český jazyk na přelomu tisiceletí. Praha: Academia, 1997, p. 146-158.

Čmejrková, S. Rod v jazyce a komunikaci: specifika češtiny. Slovo a slovesnost 63. 2002, s. $263-$ 286.

Čmejrková, S. Žena v jazyce. Slovo a slovesnost 56. 1995, p. 43-55.

Daneš, F. Ještě jednou "feministická lingvistika". Naše řeč 80. 1997, p. 256-259.

Daneš, F. Univerzalita a specifika češtiny v období globalizačních proměn. In: Čeština-univerzália a specifika 3. Hladká, S., Králík, P. (eds.) Brno: Masarykova univerzita, 2001, p. 37-47.

Doležel, L. Mathematical linguistics and automatic language processing. A group of monographs and textbooks. New York: American Elsevier Publishing Company, 1969.

Evereart, M. Vaste verbindingen (in woordenboeken). Spektator 3. 1993, p. 3-27.

Filipec, J., Čermák, F. Česká lexikologie. Praha, 1985.

Gries, S. Th. (1995). Phraeology and linguistic theory: A brief survey. In S. Granger \& F. Meunier (Eds.), Phraseology: An interdiscipilnary perspective. Amsterdam: John Benjamins Publishing Co., (p. 3-26).

Händlová, K. Contrastief taalonderzoek Nederlands-Tsjechisch: Nederlandse fraseologische vergelijkingen versus samengestelde adjectieven en hun equivalenten in Tsjechische vertalingen. Disertační práce. Praha: CUNI: FF, Ústav germánských studií. 2012. 
Hoffmannová, J. Feministická lingvistika? Naše řeč 78. 1995, č. 2, p. 80-91.

Hrnčírová Z:: Contrastieve analyse van neologismen in het Nederlands en het Tsjechisch. Acta Comenii V, Karelsuniversiteit Praag 2001, p. 161-169. (Neologismy v současné češtině a nizozemštině. Změny a posuvy v lexikální sémantice. Kontrastivní analýza obecných tendencí.)

Hrnčířová, Z.: Somatische fraseologische uitdrukkingen in het Nederlands en het Tsjechisch. Thesaurus polyglottus, Wrocław 2004, p. 151-159. (Frazeologismy s elementem "hlava" a "srdce", míra ekvivalence mezi nizozemštinou a češtinou.)

Issina, Gaukhar I. Mechsherskaya, Oxana Yu. Gender stereotypes in the Language Picture of the World. In OALib Journal [online]. 2013. [6. 1. 2015]. <http://www.erjournal.ru/ journals_n/1362429778.pdf>

Kedron, K. Akumulace a transformace kulturních informací v jazykovém vědomí národa. In: Slavistika dnes, I. Pospíśil (ed.). Brno: Masarykova univerzita, 2008, p. 57-67.

Kedron, K. Jazyk - zrcadlo kultury. In: Klićové problémy slovanských areáli̊. Brno: Masarykova univerzita, 2009, p. 54-61.

Kedron, K. Národní obraz světa a národní mentalita - př́ípad Běloruska. CEPSR (Středoevropské politické studie) 8, 2006, č. 4, dostupné z WWW: http://www.cepsr.com/index.php.

Kedron, K. Politicko-sociální aspekty vývoje běloruského jazyka ve 20. stol. Kultura slova 42. 2008, č. 3, p. 129-138.

Klötzerová, P. Hranice frazeologie se posouvají. Lexikální frazémy v češtině. Slovo a slovesnost 59. 1998, p. 277-280.

Lakoff, G, Johnson, M. Metafory, kterými žijeme. Brno: Host, 2002.

Lakoff, R. T. Language and Woman's Place. Oxford, 2004.

Mathesius, V. Jazyk, kultura a slovesnost. Praha: Odeon, 1982.

Mlacek, J. Idiomatičnost' a princíp vývinu vo frazeológii. In: Teorie a empirie. Brno: Masarykova univerzita, 2006, p. 241-252.

Pavlík, J. Elements of sociolinguistics. Bratislava: Univerzita Komenského, 2006.

Rejzek, J. Lidová etymologie a česká náboženská terminologie. Naše řeč 78. 1995, nummer 5.

Skalička, V. Vztah vývoje jazyka k vývoji společnosti. Souborné dílo. Praha: Karolinum, 2004, sv. II.

Sunderland, J. Language and gender: an advanced resource book.London: Routledge, 2006.

Talbot, Mary M. Language and Gender. Cambridge: Polity Press, 2010.

Uhlířová, L. O fragmentech „přirozeného“ obrazu světa v češtině aneb dobrodružství kognitivní lingvistik [online]. 2006, č. 4 [cit. 22 juli 2014] In Naše ř reč. <http://nase-rec.ujc.cas.cz/archiv. php?art $=7905>$.

Valdrová, J. Gender a společnost. Ústí nad Labem: Univerzita J. E. Purkyně, 2006.

Valdrová, J. "Žena a vědec? To mi nejde dohromady." Testy generického maskulina v českém jazyce. Naše ř $е \check{c} 91,2008$, č. 1 .

Valdrová, J. K české genderové lingvistice. Naše řeč 80, 1997, č. 2., p. 57-63.

Valdrová, J. Kontrastivní genderová lingvistika. Brno, 1998 a. (disertační práce).

Valdrová, J. Novinové titulky z hlediska genderu. Naše řeč 84. 2001, p. 90-96.

Valdrová, J. Sexismus v německém jazyce a situace u nás. In: Žena - Jazyk - Literatura. Ústí n. Labem: PF Univerzity J. E. Purkyně, 1996, p. 288-291.

Valdrová, J. Úvaha na téma „Čeština a žena”. Naše řeč 81.1998 b., p. 21-28.

Věšínová, E. Úvaha na téma „Čeština a žena”. Naše řě 81. 1998, č. 1, p. 21-29.

Věšínová-Kalivodová, E., Maříková, H. Společnost žen a mužů z aspektu gender. Praha: Open Society Fund, 1999.

Večerka, R. Jazyk v komparaci 1. Praha: Nakladetelství Lidové noviny, 2008.

Zábrodská, K. Variace na gender. Praha: Academia, 2009.

Zeldenrust, J. 2500 spreekwoorden: gerangschikt naar onderwerp, met betekenissen, mogelijke toepassingen en achtergrondinformatie. Groningen: Boekwerk, 1988. 